\title{
Factors Defining Shopping Experience: An Analytical Study of Dubai
}

\author{
Harvinder Singh \\ Institute of Management Technology, Ghaziabad \\ Sanjeev Prashar \\ Indian Institute of Management, Raipur
}

\begin{abstract}
This paper explains the composition of shopping experience for mall shoppers of Dubai. The study assumes significance because Dubai is a prominent destination attracting shoppers from all over the globe. An attempt has been made to portray shopper's expectations from shopping malls. The research uses data reduction with the help of Exploratory Factor Analysis (EFA) on a sample of 200 respondents from city of Dubai and condenses a set of twenty-two mall attributes into a list of five comprehensible factors. Results of the study shows that mall shoppers of Dubai view shopping experience as blend of five factors: ambience, physical infrastructure, marketing focus, convenience, and safety and security. Shoppers assign differential weightage to these factors. Composition of these factors in terms of its constituents reveals distinct patterns. Findings of this research may be used as guidelines for development and management of shopping malls in Dubai. Shopping malls making appropriate use of these insights are more likely to attract and sustain a higher level of footfalls. Capital intensive projects like shopping malls cannot afford to fail. This application-oriented study proposes new benchmarks for mall development and management and reduces the probability of taking wrong decisions. This paper is also a significant addition to the body of knowledge in the area of mall management and consumer behaviour in Dubai.
\end{abstract}

Keywords: Retail, Shopping malls, Shopping experience, Mall management, Factor analysis, Consumer behaviour.

\section{Introduction}

Dubai is the biggest tourism-cum-retail destination in the Gulf Cooperation Council (GCC) region. Traditionally these two sectors have been very closely interlinked and with over millions of tourists visiting the Emirate every year Dubai has been rightly regarded as the "Shopping capital of the Middle East" (Anwar and Sohail, 2004). While tourism is considered to be one of the most important factors in stimulating the growth in retail industry, increasing urbanization is also fostering this remarkable growth (Bagaeen, 2007). 
The UAE retail sector is expected to grow from an estimated $\$ 31$ billion in 2011 by 33\% to $\$ 41.22$ billion in 2015. Successful marketing campaigns promoting Dubai as a global shopping hub and leisure destination had driven the developmental activities (Ahmad and Murshed, 2010). The UAE boasts of a cosmopolitan population comprising of people from across the globe (Masad, 2008). Of the total UAE population, Emiratis (the natives) account for only $20 \%$ while the rest are from South Asia and Europe. A large proportion of these expatriates are employed in aviation, commerce, construction and tourism that enjoy comparatively high net worth. The consumer segment is fuelling retail sales and encouraging new market players for more developments. Average spending power of a UAE household stands at $\$ 14,400$ per annum. Emirati households contribute significantly to this with an average of $\$ 23,000$ per annum while Asian households spend $\$ 10,000$ per annum on an average (Gissing and Wallace, 2008).

World class shopping malls located in Dubai are playing a major role in promoting Dubai as a popular shopping destination. The new generations of shopping malls have established Dubai's dominance in the GCC retail industry. Shopping malls account for nearly $70 \%$ of the total retail Gross Lease Area (GLA) of Dubai. These malls also generate decent footfalls. Mall of the Emirates records nearly 2 million footfalls, Deira City Centre registers 1.5 million visitors and IbnBatuta Mall hosts just less than 1 million visitors per month.

Concept of shopping mall gets modified to meet the expectations of target market (Singh and Bose, 2008). Shopping Malls in Dubai face a unique challenge of attracting a diverse set of shoppers that include Emirati customers, Non-Emirati residents of the UAE and tourist shoppers from different parts of the world. In a way malls in Dubai not only compete with each other but also with shopping malls situated in prominent shopping-cum-tourist destinations across the globe. Since shopping malls have long gestation period, it is important for them to remain competitive over a longer period of time during their life-cycle (Singh et al. 2010). For fending -off competition malls in Dubai need to understand what excites shopper beyond the core act of shopping. A probable answer to this question is shopping experience.

\section{Research Objective}

Dubai is known for luring its tourists mainly for shopping. The city has more than 70 shopping centres including the seventh largest in the world, The Dubai Mall. Regarded as the shopping capital of Middle East there definitely existed a need to understand and study the shopping behaviour of mall shoppers in Dubai.

Since all major brands of the world are present in the malls of Dubai, it is difficult for shoppers to distinguish between two malls purely on the basis of merchandise and brands. In such cases shopping experience turns out to be an appropriate distinguishing factor as shoppers prefer a mall offering comparable merchandise but superior shopping experience (Singh and Sahay, 2012). Shopping experience is more significant for malls in Dubai as these attract shoppers from higher socio-economic strata who expect higher standards of service and experience as compared to shoppers who visit malls in many developing countries. Superior shopping experience can be created in malls if their management philosophy and practices are perfectly aligned with the expectations of shoppers. For doing so it is necessary to understand the meaning and composition of shopping experience. Present research aims at identifying the factors defining shopping experience of mall shoppers in Dubai. This research has following objectives: 
1. Identification of factors defining shopping experience in malls of Dubai.

2. Identifying relative significance of these factors.

3. Suggesting strategies for improving shopping experience in Dubai malls.

\section{Literature Review}

The act of shopping goes beyond product acquisition because consumers also shop for experiential and emotional reasons, in addition to buying goods and services. This aspect of shopping is explored by many researchers (Jones, 1999). Bellenger and Korgaonkar (1980) empirically established that a large proportion of retail shoppers are recreational shoppers who look for recreation as the key take-away. Hence retailers and mall developers should attempt to make shopping an entertaining experience to differentiate them from the competition (Talmadge, 1995; Kim et al, 2005). Csaba and Askergaard (1999) emphasised orchestration of shopping experience in light of evolution of shopping malls in America. Positive shopping experience leads to increased store liking, more time spent in store, larger ticket-size and higher incidence of unplanned purchase (Babin et al, 1994). Therefore it is crucial to add elements that improve experience quotient of shopping.

Composition of shopping experience has also been explored in past by different researchers. Holbrook \& Hirschman (1982) proposed that it goes beyond mare information processing and they added experiential perspective to it. Their model accommodated experiential view that focused on the symbolic, hedonic, and aesthetic nature of consumption. Kim et al (2005) also came up with classification as Utilitarian and Hedonic factors.

\section{Components of Shopping Experience}

Customers need entertainment and shopping malls do so by accommodating retailers offering entertainment services but this is not the only way to create entertaining experience. Shopping malls can improve shopping experience by engaging customers in an enjoyable manner while carrying out shopping. For ensuring this it is important to understand what makes shopping experience appealing. Different studies have suggested different sets of attributes as constituents of shopping experience. It is confirmed that mall shopping is a relative choice phenomenon (LeHew and Fairhurst, 2000; Lowry, 1997; Stoltman, 1991).

While exploring shopper's excitement and desire to stay at a mall, Wakefield and Baker (1998) identified four factors: ambient factors, design factors, layout and variety. Each factor was composed of multiple attributes represented by different statements. Some of the attributes covered in their study included architecture and overall design, temperature control, variety of stores, music, ease in locating stores and lighting. These attributes influence the desire to stay at a mall. In an experimentation study Matilla and Wirtz (2001) studied the impact of music and scent. Their study estimated impact of these attributes in isolation and in combination with each other.

Significance of convenience was studied by Reimers and Clulow (2009). They established its eminence irrespective of format (shopping mall or shopping strip). While doing so they considered spatial convenience, temporal convenience, car convenience, hedonic attributes and shopping services as its elements. Distance and travel time are other dimension of convenience studied in detail by Huff and Rust (1984). Their retail gravity model predicted mall patronage based on the principle of cost (accessibility) versus utility (size). They proposed retail patronage as a function of store size and distance from the consumer. 
In another study Wakefield and Baker (1998) discussed tenant-mix as variety. A more detailed and dedicated research on tenant-mix was conducted by Kirkup and Rafiq (1994). They studied tenant-mix and its relation with excitement. While studying tenant-mix in new shopping centres in UK they concluded that strong, distinctive and consistent tenant-mix is crucial for success of a shopping centre. Other studies point out that shoppers prefer malls with rich and diverse tenant-mix. A diverse tenant-mix also infuses sense of excitement in a mall. These results are supported by recent studies (Brito, 2009) which indicate that store selection and tenant-mix are key attributes shaping mall image and influencing patronage decisions.

In context of Dubai malls, El-Adly (2007) identified six factors determining mall attractiveness from shopper's perspective. These were comfort, entertainment, diversity, mall essence, convenience, and luxury. In Indian context an Indian study by Venkateswarulu and Uniyal (2007) proposed a set of attributes for shopping malls in the city of Mumbai (India). They found that attractiveness of a mall depends on appeal and convenience, amenities and atmospherics, ambience, personnel, parking and seating. They also suggested some new attributes like restrooms (utilities), smell (odour), parking, security and size of stores.

Marketing activities and marketing focus of shopping malls was studied by Chattopadhyaya and Sengupta (2006) while studying shopping malls in Kolkata. They found that distinctive positioning of shopping malls is attributable to appropriate marketing strategies and these also resulted in increased customer patronage.

\section{Research Methodology}

It is a cross-sectional study involving observation of a representative sample of the population all at the same time. This research was conducted in two phases. First phase was exploratory in nature involving analysis of secondary data and personal interactions with select industry professionals, researchers/academicians and mall shoppers. It helped in defining the problem and generating a structured questionnaire. Second phase was conclusive (descriptive) and involved collection of data from respondents.

Review of literature provided the initial list of attributes affecting shopping experience. It was shared with a panel comprising of researchers and practioners. Panel examined all the variables in terms of their suitability for present research. Final instrument comprised of twenty two mall attributes. It was designed to measure respondent's level of agreement or disagreement with statements regarding significance of each attribute. Five-point Likert's scale was used to record the responses. In this scale a rating of ' 1 ' indicates strong disagreement whereas a rating of ' 5 ' represents strong agreement. Research instrument was pre-tested to check its validity and reliability. Research instrument also included questions on key demographic attributes of respondents.

During descriptive phase of research, research instrument was administered to respondents. Number of cases should be atleast five times the number of variables (attributes) if factor analysis is to be applied successfully (Bryant and Yarnold, 1995; Hair et al, 2006). Since this study involved examining twenty two variables, minimum sample required was 110. Sample size for this study was kept at 200 to rule-out any deficiency on this count.

Population for the research was defined as people who actually carry out shopping in malls. Sampling element was individual shopper. Sampling unit was shopping malls from where the 
elements were drawn. Extent to which people are included in sample is defined in terms of a criterion (preferably objective) that defines elements. In this research, extent was expressed as persons carrying minimum of one shopping bag in their hands while coming out of a mall.

Data for this study was collected from four malls - The Dubai Mall, Mall of the Emirates, Deira City Centre and Mirdiff City Centre. These malls were selected since these registered maximum foot fall among all the malls in Dubai during 2010 and were likely to provide a representative sample of the shoppers visiting malls in Dubai. These malls cover all major locations as well as customer strata of target population. The Dubai Mall with Gross Leasable Area of 3.77 million square feet is situated on Doha Road in close vicinity of BurjKhalifa, world's tallest free-standing building. The 2.4 million square feet large Mall of the Emirates is situated in Al Barsha district of Dubai. Deira City centre measures 1.3 million square feet and is situated in Port Saeed locality of Dubai. Mirdiff City Centre is situated in Mirdiff area of Dubai and measures nearly 2 million square feet. 
Table I: Summary Information on Shopping Malls

\begin{tabular}{|l|l|l|l|l|}
\hline & The Dubai Mall & $\begin{array}{l}\text { Mall of } \\
\text { Emirates }\end{array}$ & $\begin{array}{l}\text { Deira City } \\
\text { Centre }\end{array}$ & $\begin{array}{l}\text { Mirdif City } \\
\text { Centre }\end{array}$ \\
\hline Starting year & 2008 & 2005 & 1995 & 2010 \\
\hline Developer & $\begin{array}{l}\text { EMAAR } \\
\text { Properties }\end{array}$ & $\begin{array}{l}\text { MAF } \\
\text { Properties }\end{array}$ & $\begin{array}{l}\text { Majid Al Futtaim } \\
\text { Properties }\end{array}$ & $\begin{array}{l}\text { Majid Al Futtaim } \\
\text { Properties }\end{array}$ \\
\hline Location & Doha Road & $\begin{array}{l}\text { Al-Bashra } \\
\text { District }\end{array}$ & Port Saeed & Mirdiff \\
\hline $\begin{array}{l}\text { Gross Leasable } \\
\text { Area }\end{array}$ & \multicolumn{1}{|c|}{3.77} & 2.4 & 1.3 & \multicolumn{1}{|c|}{2} \\
\hline $\begin{array}{l}\text { Number of } \\
\text { outlets }\end{array}$ & 1200 & \multicolumn{1}{|c|}{520} & 350 \\
\hline $\begin{array}{l}\text { Prominent } \\
\text { Tenants }\end{array}$ & $\begin{array}{l}\text { Bloomingdale's } \\
\text { Debenhams } \\
\text { Marks \& } \\
\text { Spencer } \\
\text { Virgin } \\
\text { Megastore } \\
\text { Reel Cinemas } \\
\text { Dubai Ice Rink } \\
\text { Dubai Aquarium }\end{array}$ & $\begin{array}{l}\text { Debenhams } \\
\text { Marks \& } \\
\text { Spencer } \\
\text { Virgin } \\
\text { Megastore } \\
\text { Carrefour } \\
\text { Vox Cinemas } \\
\text { Centrepoint }\end{array}$ & $\begin{array}{l}\text { Debenhams } \\
\text { Marks \& Spencer } \\
\text { Woolworths } \\
\text { Carrefour } \\
\text { Vox Cinemas } \\
\text { Bowling City } \\
\text { Magic Planet }\end{array}$ & $\begin{array}{l}\text { Debenhams } \\
\text { Carrefour } \\
\text { Home Centre } \\
\text { Emax } \\
\text { Vox Cinemas } \\
\text { Playnation } \\
\text { Aquaplay }\end{array}$ \\
\hline
\end{tabular}

Non-probability quota sampling was used in this research. It is a multi-stage restricted judgmental sampling in which first stage consists of developing control categories or quota of population elements while subsequent stages involves selection of sample elements based on convenience or judgment (Malhotra, 2004). First stage resulted in development of control categories or quotas in the form of four malls in Dubai. Second stage involved selecting respondents on the basis of convenience and judgment. Fifty respondents were selected from each mall. Malls were selected in a manner that these represent all major shopping areas and population strata of Dubai. Mall intercept method was chosen to approach shoppers.

The Dubai Mall and Mall of the Emirates cater predominantly to upscale populace besides being a major attraction for tourists. Management of these malls understands role of entertainment and location in evolving retail mix strategy that would eventually provide competitive advantage in the retail environment. The other two malls are popular among Emiratis and mid-income segment of expatriate population for shopping. On the whole sample of respondents from these four malls provide an understanding of the requirements of tourists, natives and expatriates from upper and mid-income segments. 


\section{Data Analysis \& Interpretation}

Demographic information collected with the help of questionnaire was used to develop a profile of mall shoppers in Dubai using simple numbers and percentages. Data relating to mall attributes was subjected to data reduction with help of factor analysis using SPSS.

\section{Profile of respondents}

Sample depicted composition of working population in Dubai as it comprised predominantly of males. $88 \%$ of respondents were in economically productive age group 20 years -50 years with majority $(59.5 \%)$ being in prime of their youth i.e. 20 years -35 years. More than half the population was married (but not necessarily accompanied by the spouse during data collection). Half the respondents were graduates. $29 \%$ of respondents were either postgraduates or having a higher qualification. Respondents with only school education or professional education constituted a minor fraction of the total sample with $7.5 \%$ and $13.5 \%$ respectively. Understandably more than half the sample (54.5) was employed with private sector while remaining proportion of sample was divided between four occupations Sample was evenly spread in terms of income distribution with all income categories contributing a significant proportion to the sample.

Table II: Profile of Respondents

\begin{tabular}{|c|c|c|c|}
\hline Demographic Group & Demographic categories & Number & Percentage \\
\hline \multirow[t]{4}{*}{ Age Group } & 13-19 years & 12 & 6.0 \\
\hline & $20-35$ years & 119 & 59.5 \\
\hline & $36-50$ years & 57 & 28.5 \\
\hline & $51-65$ years & 12 & 6.0 \\
\hline \multirow[t]{2}{*}{ Gender } & Male & 140 & 70 \\
\hline & Female & 60 & 30 \\
\hline \multirow[t]{3}{*}{ Marital Status } & Unmarried & 79 & 39.5 \\
\hline & Married & 113 & 56.5 \\
\hline & Widow(er)/Divorcee & 8 & 4.0 \\
\hline \multirow[t]{4}{*}{ Education Level } & Schooling & 15 & 7.5 \\
\hline & Graduation & 100 & 50 \\
\hline & PG \& above & 58 & 29 \\
\hline & Professional & 27 & 13.5 \\
\hline \multirow[t]{5}{*}{ Occupation } & Government Service & 15 & 7.5 \\
\hline & Private Service & 109 & 54.5 \\
\hline & Professional & 27 & 13.5 \\
\hline & Business & 14 & 7.0 \\
\hline & \begin{tabular}{|l|} 
Student \\
\end{tabular} & 35 & 17.5 \\
\hline \multirow{4}{*}{ Monthly Income } & Less than $\$ 2000$ & 54 & 27 \\
\hline & $\$ 2000-4000$ & 72 & 36 \\
\hline & $\$ 4000-6000$ & 42 & 21 \\
\hline & More than $\$ 6000$ & 32 & 16 \\
\hline All Data & & 200 & 100 \\
\hline
\end{tabular}




\section{Factor Output:}

Data was checked for suitability for factor analysis with help of correlation analysis, KMO test of sampling adequacy and Bartlett's test of sphericity (Boyd et al, 2002; Malhotra, 2004). Most variables had significant correlation between them. Both KMO Test of Sampling Adequacy value and Bartlett's Test of Sphericity value were found adequate (Table II). However when data was subjected to Principal Component Analysis (PCA), communality value of some of the variables was less than 0.5 . Those variables also had insignificant factor loadings. For refining result variables with lesser communality values were deleted following an iterative procedure. After three iterations resulting in deletion of three variables optimum output was obtained. This data set was checked for suitability for factor analysis.

Table III: KMO \& Bartlett's Test of Sphericity

\begin{tabular}{|l|l|c|}
\hline Kaiser-Meyer-Olkin Measure of Sampling Adequacy. & .809 \\
\hline \multirow{3}{*}{ Bartlett's Test of Sphericity } & Approx. Chi-Square & 1909.430 \\
\cline { 2 - 3 } & Df & 171 \\
\cline { 2 - 3 } & Sig. & .000 \\
\hline
\end{tabular}

Data set was then subjected to another round of Principal Component Analysis and Varimax rotation. Communalities for all nineteen variables were higher than 0.5 (Annexure I) indicating it to be an optimum solution. Final solution explained $69.775 \%$ of total variance associated with the problem (Annexure II). Factor output comprised of five factors based on nineteen variables (Annexure III). Relevant factor loadings for each variable indicated that all the variables wre adequately explained by derived factors.

Factor output comprised of five factors representing specific forces shaping shopping experience in Dubai malls. These are presented in the table given below. 
Table IV: Consolidated Factor Output\& Allied Information

\begin{tabular}{|c|c|c|c|c|c|c|}
\hline $\begin{array}{l}\text { Factor } \\
\text { No. } \\
\text { (Variance } \\
\text { explained) }\end{array}$ & Factor Title & $\begin{array}{l}\text { Variables } \\
\text { included } \\
\text { (Av. Score) }\end{array}$ & $\begin{array}{l}\text { Factor } \\
\text { loading } \\
\text { Loading }\end{array}$ & $\begin{array}{l}\text { Cronbach's } \\
\text { Alpha }\end{array}$ & $\begin{array}{l}\text { Average } \\
\text { score/ } \\
\text { factor }\end{array}$ & $\begin{array}{l}\text { Factor } \\
\text { Ranking }\end{array}$ \\
\hline \multirow[t]{6}{*}{$\begin{array}{l}\text { F1 } \\
23.635 \%\end{array}$} & \multirow[t]{6}{*}{ Ambience } & $\begin{array}{l}\text { Illumination } \\
(3.225)\end{array}$ & .926 & \multirow{6}{*}{0.928} & \multirow{6}{*}{3.19} & \multirow{6}{*}{ II } \\
\hline & & $\begin{array}{l}\text { Temperature } \\
\text { control }(3.14)\end{array}$ & .904 & & & \\
\hline & & $\begin{array}{l}\text { Background } \\
\text { music }(3.205)\end{array}$ & .851 & & & \\
\hline & & $\begin{array}{l}\text { General } \\
\text { hygiene (3.215) }\end{array}$ & .840 & & & \\
\hline & & $\begin{array}{l}\text { Ambient Odour } \\
(3.125)\end{array}$ & .807 & & & \\
\hline & & $\begin{array}{l}\text { Landscaping } \\
(3.250)\end{array}$ & .797 & & & \\
\hline \multirow{4}{*}{$\begin{array}{l}\text { F2 } \\
14.087 \%\end{array}$} & \multirow[t]{4}{*}{ Convenience } & Utilities (2.065) & .888 & \multirow{4}{*}{0.815} & \multirow{4}{*}{1.88} & \multirow{4}{*}{ IV } \\
\hline & & $\begin{array}{l}\text { Distance of } \\
\text { mall from } \\
\text { home }(1.73)\end{array}$ & .823 & & & \\
\hline & & $\begin{array}{l}\text { Lifts \& } \\
\text { Escalators } \\
(1.885)\end{array}$ & .719 & & & \\
\hline & & $\begin{array}{l}\text { Floor Plan } \\
(1.855)\end{array}$ & .664 & & & \\
\hline \multirow[t]{4}{*}{$\begin{array}{l}\text { F3 } \\
13.698 \%\end{array}$} & \multirow[t]{4}{*}{$\begin{array}{l}\text { Physical } \\
\text { Infrastructure }\end{array}$} & $\begin{array}{l}\text { Size of the mall } \\
(3.05)\end{array}$ & .815 & \multirow{4}{*}{0.804} & \multirow{4}{*}{2.985} & \multirow{4}{*}{ III } \\
\hline & & $\begin{array}{l}\text { Parking space } \\
(2.7)\end{array}$ & .791 & & & \\
\hline & & $\begin{array}{l}\text { Open } \quad \text { space } \\
(3.25)\end{array}$ & .783 & & & \\
\hline & & $\begin{array}{l}\text { Size of Atrium } \\
(2.94)\end{array}$ & .720 & & & \\
\hline \multirow[t]{3}{*}{$\begin{array}{l}\text { F4 } \\
9.394 \%\end{array}$} & \multirow[t]{3}{*}{$\begin{array}{l}\text { Marketing } \\
\text { Focus }\end{array}$} & $\begin{array}{l}\text { Promotional } \\
\text { events (4.05) }\end{array}$ & .800 & \multirow{3}{*}{0.622} & \multirow{3}{*}{3.96} & \multirow{3}{*}{$\mathbf{I}$} \\
\hline & & $\begin{array}{ll}\text { Mall façade } \\
(3.31)\end{array}$ & .728 & & & \\
\hline & & $\begin{array}{l}\text { Tenant-mix } \\
(4.53)\end{array}$ & .671 & & & \\
\hline \multirow[t]{2}{*}{$\begin{array}{l}\text { F5 } \\
8.961 \%\end{array}$} & \multirow[t]{2}{*}{$\begin{array}{l}\text { Safety } \quad \& \\
\text { Security }\end{array}$} & $\begin{array}{l}\text { Compliance } \\
\text { with } \\
\text { construction } \\
\text { laws }(1.235) \\
\end{array}$ & .900 & \multirow{2}{*}{0.796} & \multirow{2}{*}{1.3125} & \multirow{2}{*}{$\mathbf{V}$} \\
\hline & & $\begin{array}{l}\text { Security } \\
\text { against acts of } \\
\text { terror } \\
(1.39)\end{array}$ & .894 & & & \\
\hline
\end{tabular}




\section{(a) Factor 1}

This factor explained maximum variance (23.635) and comprised of six variables namely illumination, temperature control, background music, general hygiene, ambient odour and landscaping. All these variables contribute to soft or hedonic aspects of shopping. Past researchers labelled similar bundles of variables as 'ambience' since affirmative action of these fronts improve ambience of a retail unit. All six variables had very high factor loadings on factor one. It ranged from 0.926 (for illumination) to 0.797 (for landscaping). However average score for factor 1 was 3.19 (second-highest out of five extracted factors) indicating that shoppers did consider ambience significant for shopping experience but urge for the same was not so intense. Probably it was due to refined profile and higher expectations of Dubai shoppers as compared to shoppers in developing countries. Since all the variables constituting this factor have similar scores (ranging from 3.125 to 3.250 ) it may be safely assumed that all variables were equally significant for shoppers.

\section{(b) Factor 2}

Second factor extracted in this research explained $14.087 \%$ of variance. It comprised of four variables; utilities, distance of mall from home/place of stay, lifts and escalators and floor plan. These aspects add to comfort and convenience while shopping by making it easier for shoppers to reach and navigate through mall. Therefore this factor was labelled as 'convenience'. Factor loadings for all four variables were significant ranging between 0.888 and 0.664. Average score per facto for factor two was 1.88 making it one of the least significant factors adding to shopping experience. Across variables, average score didn't show much divergence except for utilities for which average score was above 2 (2.065). Probably it was due to the fact that Dubai is a compact city with world-class infrastructure and connectivity where convenience does not figure at all in the list of expectations that shoppers have from shopping malls.

\section{(c) Factor 3}

Third factor explained $13.698 \%$ of variance. Four variables comprising it were size of the mall, parking space, open Space and size of atrium. These variables represent physical attributes of a shopping mall hence this factor was labelled as 'physical infrastructure'. Factor loading for these four variables ranged from 0.815 to 0.720 . Average score per factor for this factor turned out to be 2.985 indicating neutral attitude of shoppers towards physical infrastructure. However constituent variables carry varied significance. Parking space with average score of 2.7 is least significant whereas open space with average score of 3.25 is most important. It seemed that mall shoppers of Dubai were not over-awed by superior dimensions of malls in Dubai. It could be that they find all the malls offering equal physical infrastructure.

\section{(d) Factor 4}

Fourth factor extracted in this study explained $9.394 \%$ of variance. It contained variables like promotional events, mall facade and tenant-mix. These variables seemingly relate to activities covered under different functions. For instance promotional events relate to marketing, designing a mall facade is a part of mall architecture and tenant-mix is a part of commercial leasing activity. However all these variables underline a common theme: attempt to attract customers to a mall. Promotional activities are directed towards shoppers, facade makes a mall more attractive to people who see it and a balanced tenant-mix makes it more attractive to shoppers. So it was apt to label it as 'marketing focus'. Average score per factor for factor four was 3.96, the highest among all five factors. It indicated that customers were more interested in marketing focus of the malls they patronize. A deeper peep into the scores 
revealed that tenant-mix was the strongest component with average score of 4.53 , the highest score for any variable in this study.

\section{(e) Factor 5}

The last factor explained $8.961 \%$ of total variance associated with the problem. It had only two variables in it namely 'safety from crimes' and 'security against acts of terror'. Both the variance point towards 'safety and security' aspects of malls hence labelled the same. It turned out to be the least significant factor with lowest average score per factor (1.3125). Both statements had average score close to 1 (1.235 \& 1.390 respectively) indicating that safety and security was not an intense concern for mall shoppers in Dubai. Root of this believe could stem from the fact that UAE did not experience any act of terror or crime in shopping malls in past.

\section{Ranking of factors:}

Relative significance of factors is judged by ranking of factors which in turn is assessed calculating average score per factor. Results presented in Table III indicate that marketing focus was the most desirable factor (average score 3.96). Another factor very relevant to shoppers was 'ambience' (average score 3.19), 'physical infrastructure' and 'convenience' were ranked third and fourth though their average score was less than 3 and 2 respectively. 'Safety and security' was the least significant factor with score of just 1.3125.

\section{Validity\& Reliability of Factor Output}

Validity \& reliability of factor output was checked statistically. Reliability was established by estimating Cronbach's Alpha for each factor (Table III). Alpha value for all the factors was greater than 0.6 indicating the output to be reliable.

Convergent validity for a factor indicates that all variables constituting a single factor actually converge into it i.e. they share a high proportion of variance in common. Convergent validity was checked with the help of 'Variance Extracted (VE)'. VE is calculated by adding squared factor loadings for all variables constituting a factor and then dividing it by number of variables.

Table V: Variance Extracted By Each Factor

\begin{tabular}{|l|l|c|}
\hline S. No & Factor No. \& Label & Variance Extracted (VE) \\
\hline $\mathbf{1}$ & F1 (Ambience) & 0.732 \\
\hline $\mathbf{2}$ & F2 (Convenience) & 0.606 \\
\hline $\mathbf{3}$ & F3 (Physical Infrastructure) & 0.605 \\
\hline $\mathbf{4}$ & F4 (Marketing Focus) & 0.540 \\
\hline $\mathbf{5}$ & F5 (Safety \& Security) & 0.805 \\
\hline
\end{tabular}

Table IV show that Variance Extracted for each of the five factors was higher than 0.5. Discriminant validity establishes that the factors extracted are truly distinct from each other. It is established by observing factor loading for each variable under all factors. Final factor output showed that there was complete absence of cross loading. 


\section{Discussion on Results}

Results of this study validate the notion that shopping experience is interplay of a number of factors. For providing superior shopping experience one should take an integrated view of the situations and work on multi-pronged strategies. These strategies may be designed in light of following observations made in this research:

\section{Composition of shopping experience:}

This study revealed that shopping experience comprise of five factors: ambience, convenience, physical infrastructure, marketing focus and safety and security. Shopping experience offered by a mall is cumulative impact of service(s) offered under each factor. It means that shopping malls can offer unique and differentiated shopping experience to their shoppers by carefully selecting facilities and services under each factor. This selection would depend upon customer preferences and competitive environment.

\section{Differential Impact of factors:}

Though shopping experience comprises of five factors, all of them do not contribute equally to it. Average score per factor is a good indicator of significance attached by shoppers to each of these factors. In this study, average score per factor ranged from 3.96 to 1.3125 . It means mall developers and managers need not emphasise all the factors simultaneously. It is important to know this as each decision aimed at improving experience related to a factor would require commitment of resources. Since resources carry cost it is important to identify activities/decisions related to the most relevant factor so that resources can be optimally allocated.

\section{Relative Significance of factors:}

Present study reflected that marketing focus is the most significant factor for shoppers in terms of shopping experience. It was followed by ambience, physical infrastructure, convenience and safety \& security. It is not a big surprise that marketing focus merged as the number one factor since Dubai has been actively and effectively attracting shoppers from all over the globe. Ambience was the only other factor evoking warm response from shoppers. All other factors had average scores less than three.

\section{Composition of factors:}

Another interesting insight from this research is the internal composition of each factor. For instance 'ambience' comprised of six factors. It is natural to have variables like illumination, temperature control, ambient odour, music and landscaping under ambience. But inclusion of general hygiene under ambience is an eye-opener. It meant that mall shoppers in Dubai do not consider general hygiene' as a routine function of housekeeping that is more of a 'hygiene' function (taking a cue from the two factor theory of motivation). Rather, it is a motivational factor adding to ambience of the place. 
Results of this study should be viewed as a blending of general theory of consumer behaviour viewed through the looking glass of population of Dubai. Like shoppers in any other part of the world, shoppers of Dubai also view shopping experience interplay of a number of factors. When compared with similar studies conducted in different parts of the world, number and labelling of factors was expected to be more or less similar as core human needs are common across geographies and cultures. However similarity ends here only. Different cultures, economies and geographies might select different means or solutions to gratify same core need. In this context it is very important to look into composition of individual factors (in terms of its constituent variables) and also weightage assigned to these factors and/or variables. Since target population comprises of high-income, widely travelled individuals (Emirati, expatriates and tourists) and most of them are high on education, awareness and connectivity with the world, they are expected to have a higher level of expectations from shopping malls. It is because they have global benchmarks to compare with.

A similar study in context of shopping malls of Delhi NCR in India by Singh \&Sahay (2012) indicated that Indian shoppers consider ambience to be the most important factor whereas marketing focus is the foremost factor for Dubai shoppers. Indian inferences are quite similar to those observed in studies conducted in many developed countries (Babin et al, 1994; Wakefield \& Baker, 1998; Jones, 1999; Kim et al, 2005). Difference in response might be attributable to different attributes of shoppers (domestic versus visitors/tourists). This notion is justified by some studies where domestic shoppers and tourists evaluated same products/services differently (Yuksel, 2004).

Marketing focus is the foremost factor defining shopping experience for shoppers in Dubai and it goes in line with positioning of Dubai as a shopping destination. Government of Dubai has been actively promoting UAE as a business-cum-shopping destination. People who visit these malls (especially expatriates and tourists) are attracted by this proposition. A close look at average score per variable indicates that tenant-mix is the most significant variable under 'marketing focus'. Mall shoppers in Dubai feel excited when they see a rich tenant-mix. It is important for mall developers and managers to ensure their selection of brands is such that shoppers feel excited about visiting their malls. A significant aspect of it is that Dubai malls need to communicate to audience spread over a much wider geography as compared to malls elsewhere in the world as catchment area of Dubai malls is not confined to the city of Dubai.

\section{Limitations of this Study}

This research is cross-sectional in nature and results are prone to impact of time. A longitudinal research with a series of data sets collected after a regular interval would insulate the impact of time. Size of the sample is sufficient to overcome the statistical objections but is still very small as compared to total population. Another limitation of this study is that results are based on the assumption that the sample is a monolith whereas different segments within it may exhibit different preferences. It was not done division of this sample into subsamples (age-wise, gender-wise, income-wise) would have further reduced number of observations (respondents) under each sub-segment. However it is possible to address this issue with a larger sample and/or adopting quota sampling. It would be interesting to identify similarities/dissimilarities between genders, age-groups and income segments. 


\section{Directions for Future Research}

Looking beyond composition of shopping experience for a single geographic or cultural market, it would be useful to collect a sample cutting across geographic or cultural boundaries. Such a study would help in highlighting differences between two markets and also point at possible sources/reasons for such differences. For single-market studies, deeper insight can be obtained by studying differences along demographic parameters of respondents like age, gender, income, occupation etc. Such a study would help practitioners in devising segment specific strategies.

\section{Conclusion}

Results of study reveal interesting patterns in terms of composition of shopping experience. Results can be used by mall developers and mall managers to make sure that they are able to provide superior shopping experience to their shoppers. It is all the more important for Dubai as it attracts shoppers from all across the globe. However as time progresses, more and more countries shall have world-class malls. In that scenario some of the shoppers may satisfy their urge by visiting newly constructed world-class malls in their own countries or they may prefer some other shopping destination. So Dubai malls need to re-invent themselves in terms of elements of shopping experience so as to keep themselves relevant in the eyes of their target group.

\section{References}

Ahmad, S. \& M. Murshed (2011). GCC Retail Industry. Report by Alpen Capital, UAE.

Anwar, S.A. \&Sohail, S. M. (2004). Festival Tourism in the United Arab Emirates: First-time Versus Repeat Visitor Perceptions. Journal of Vacation Marketing, 10 (2): 161-170.

Babin, B. J., Darden, W. R. \& M. Griffin (1994). Work and/or Fun: Measuring Hedonic and Utilitarian Shopping Value. Journal of Consumer Research, 20 (March): 644-656.

Bagaeen, S. (2007). Brand Dubai: The Instant City; or the Instantly Recognizable City. International Planning Studies, 12 (2): 173-197.

Bellenger, D. N. \& P. K. Korgaonkar (1980). Profiling the Recreational Shopper. Journal of Retailing, 56 (3): 77-92.

Boyd, H. W., Westfall, R. \& S. F. Stasch (2002). Marketing Research-Text \& Cases- $^{\text {th }}$ Ed. New Delhi, AITBS.

Brito, P. Q. (2009). Shopping Centre Image Dynamics of a New Entrant.International Journal of Retail and Distribution Management37 (7): 580-599.

Bryant, F. B. \& P. R. Yarnold (1995).Principal Components Analysis and Exploratory and Confirmatory Factor Analysis.In L. G. Grimm and R R. Yarnold, Reading and Understanding Multivariate Statistics. Washington DC, American Psychological Association: 99-136. 
Chattopadhyaya, A. \& K. Sengupta (2006). Perception of Mall Shoppers in Kolkata: A Study. The ICFAI Journal of Consumer Behaviour.1 (3): 34-43.

Csaba, F. F. \& S. Askergaard (1999).Malls and the Orchestration of the Shopping Experience in a Historical Perspective.Advances in Consumer Research, 26: 34-40.

El-Adly, M. I. (2007). Shopping Malls Attractiveness: A segmentation Approach. International Journal of Retail and Distribution Management.35 (11): 936-950.

Gissing, S. \& D. Wallace (2008). Dubai Retail Snapshots. Dubai, Colliers International.

Hair, J. H., Blake, W. C., Babin, B. J., Anderson, R. E. \& R. L. Tatham (2006). Multivariate Data Analysis- $6^{\text {th }}$ edition. New Delhi, Pearson Education.

Holbrook, M. B. \& E. C. Hirschman (1982). The Experiential Aspects of Consumption: Consumer Fantasies, Feelings, and Fun. Journal of Consumer Research.9 (September): 132-240.

Huff, D. L. \& R. T. Rust (1984).Measuring the Congruence of a Trading Area.Journal of Marketing.48 (4): 68-74.

Jones, M. A. (1999). Entertaining Shopping Experiences: An Exploratory Investigation.Journal of Retailing \& Consumer Services. 6 (3): 129-139.

Kim, Y., Jikeyong, K. \& K. Minsung (2005). The Relationship Among Family and Social Interaction, Loneliness, Mall Shopping Motivation and mall Spending of Older Consumers. Psychology \& Marketing. 22 (12): 47-53.

Kirkup, M. H. \& M. Rafiq (1994).Tenancy Development in New Shopping Centres.International Review of Retail, Distribution and Consumer Research.4 (3): 345-360.

LeHew, M. L. A. \& A. E. Fairhurst (2000). US Shopping Mall Attributes: An Exploratory Investigation of their Relationship to Retail Productivity. International Journal of Retail \& Physical Distribution.28 (6): 261-279.

Lowry, J. R. (1997). Life Cycle of Shopping Centres.Business Horizons.January-February: 77-86.

Masad, M. (2008). Dubai: What cosmopolitan city. ISIM Review.22 (autumn): 10-11.

Malhotra, N. (2004). Marketing Research-An Applied Orientation, $4^{\text {th }}$ Ed. New Delhi, Pearson Education.

Matilla, A. S. \& J. Wirtz (2001).Congruence of Scent and Music as a Driver of In-store Evaluations and Behaviour.Journal of Retailing. 77 (2): 273-289.

Reimers, V. \& V. Clulow (2009). Retail Centres: It's Time to Make Them Convenient. International Journal of Retail and Distribution Management. 37 (7): 541-562. 
Singh, H. \& S. K. Bose (2008). My American Cousin: A Comparison between Indian and the US Shopping Malls. Journal of Asia-Pacific Business. 9 (4): 358-372.

Singh, H.; Bose, S. K., \& V. Sahay (2010). Management of Indian Shopping Malls: Impact of the Pattern of Financing. Journal of Retail and Leisure Property.9 (1): 55-64.

Singh, H. \& V. Sahay (2012). Determinants of Shopping Experience: Exploring the Mall Shoppers of National Capital Region (NCR) of India. International Journal of Retail and Distribution Management.40 (3): 235-248.

Stoltman, J. J., Gentry, J. W. \& K. A. Anglin (1991). Shopping Choices: The Case of Mall Choice.Advances in Consumer Research.18: 434-440.

Talmadge, C. (1995). Retailers Injecting More Fun into Stores.Advertising Age. 66 (44): 38.

Venkateswarulu, A. \& D. P. Uniyal (2007). Concept of a Mall: Measuring Attitude and Perception of Shoppers towards Malls of Mumbai. Indian Retail Review.1 (1): 7-16.

Wakefield, K. L. \& J. Baker (1998). Excitement at the Mall: Determinants and Effects on Shopping Response. Journal of Retailing.74 (4): 515-539.

Yuksel, A. (2004). Shopping Experience Valuation: A Case of Domestic and International Visitors. Tourism Management.25: 751-759.

http://www.deiracitycentre.com/en/article/global/about-dcc.html, accessed on May 23, 2012.

http://www.malloftheemirates.com/en/article/global/about-moe.html, accessed on May 23, 2012.

http://www.mirdifcitycentre.com/en/article/global/about-us.html, accessed on May 23, 2012.

http://www.thedubaimall.com/en/news/media-centre/news-section/the-dubai-mall-opens-largest.html, accessed on May 23, 2012. 
ANNEXURE I: Communality Values

\begin{tabular}{|l|c|c|}
\hline & Initial & Extraction \\
\hline Distance of mall from home & 1.000 & .682 \\
\hline Mall façade & 1.000 & .559 \\
\hline Temperature control & 1.000 & .834 \\
\hline General hygiene & 1.000 & .719 \\
\hline Size of Atrium & 1.000 & .611 \\
\hline Floor Plan & 1.000 & .514 \\
\hline Tenant-mix & 1.000 & .520 \\
\hline Parking space & 1.000 & .685 \\
\hline Ambient Odour & 1.000 & .683 \\
\hline Promotional events & 1.000 & .693 \\
\hline Utilities & 1.000 & .826 \\
\hline Security against acts of terror & 1.000 & .815 \\
\hline Background music & 1.000 & .747 \\
\hline Illumination & 1.000 & .872 \\
\hline Size of the mall & 1.000 & .683 \\
\hline Lifts \& Escalators & 1.000 & .637 \\
\hline Open space & 1.000 & .700 \\
\hline Landscaping & 1.000 & .651 \\
\hline Compliance with construction laws & 1.000 & .826 \\
\hline Extraction Method: Principal Component Analysis. & \\
\hline
\end{tabular}

ANNEXURE II: Total Variance Explained For Nineteen Variable Problem Total Variance Explained

\begin{tabular}{|c|c|c|c|c|c|c|c|c|c|}
\hline \multirow[b]{2}{*}{ Comp } & \multicolumn{3}{|c|}{ Initial Eigen values } & \multicolumn{3}{|c|}{\begin{tabular}{|l|} 
Extraction Sums of Squared \\
Loadings
\end{tabular}} & \multicolumn{3}{|c|}{$\begin{array}{l}\text { Rotation Sums of Squared } \\
\text { Loadings }\end{array}$} \\
\hline & Total & $\begin{array}{l}\% \text { of } \\
\text { Variance }\end{array}$ & Cum.\% & Total & $\begin{array}{l}\% \text { of } \\
\text { Variance }\end{array}$ & Cum.\% & Total & $\begin{array}{l}\% \text { of } \\
\text { Variance }\end{array}$ & Cum.\% \\
\hline 1 & 4.985 & 26.235 & 26.235 & 4.985 & 26.235 & 26.235 & 4.491 & 23.635 & 23.635 \\
\hline 2 & 3.376 & 17.767 & 44.001 & 3.376 & 17.767 & 44.001 & 2.677 & 14.087 & 37.722 \\
\hline 3 & 1.969 & 10.363 & 54.365 & 1.969 & 10.363 & 54.365 & 2.603 & 13.698 & 51.420 \\
\hline 4 & 1.515 & 7.972 & 62.336 & 1.515 & 7.972 & 62.336 & 1.785 & 9.394 & 60.814 \\
\hline 5 & 1.413 & 7.439 & 69.775 & 1.413 & 7.439 & 69.775 & 1.703 & 8.961 & 69.775 \\
\hline
\end{tabular}


ANNEXURE III: Rotated Component Matrix for Nineteen Variable Problem

\begin{tabular}{|l|c|c|c|c|c|}
\hline & \multicolumn{5}{|c|}{ Component } \\
\hline & 1 & 2 & 3 & 4 & 5 \\
\hline Illumination & .926 & .075 & .035 & .036 & .077 \\
\hline Temperature control & .904 & .120 & -.011 & .044 & -.005 \\
\hline Background music & .851 & .092 & -.113 & .039 & -.024 \\
\hline General hygiene & .840 & .072 & .021 & .009 & .091 \\
\hline Ambient Odour & .807 & .135 & -.072 & .081 & .033 \\
\hline Landscaping & .797 & -.002 & .112 & -.022 & .053 \\
\hline Utilities & .086 & .888 & .120 & .121 & .039 \\
\hline Distance of mall from home & .029 & .823 & -.022 & .047 & .037 \\
\hline Lifts \& Escalators & .133 & .719 & .268 & .166 & .049 \\
\hline Floor Plan & .172 & .664 & .174 & .101 & .056 \\
\hline Size of the mall & .052 & -.070 & .815 & .103 & -.020 \\
\hline Parking space & -.081 & .139 & .791 & -.180 & -.016 \\
\hline Open space & -.010 & .203 & .783 & .211 & .032 \\
\hline Size of Atrium & .001 & .271 & .720 & .086 & -.110 \\
\hline Promotional events & .146 & .150 & -.032 & .800 & .092 \\
\hline Mall façade & -.036 & .041 & .059 & .728 & -.152 \\
\hline Tenant-mix & .019 & .167 & .143 & .671 & .142 \\
\hline $\begin{array}{l}\text { Compliance with construction } \\
\text { nnwr }\end{array}$ & .094 & .052 & -.015 & .055 & .900 \\
\hline Security against acts of terror & .050 & .087 & -.076 & .003 & .894 \\
\hline Extraction Method: Principal Component Analysis. & & & & \\
\hline Rotation Method: Varimax with Kaiser Normalization. & & & & \\
\hline a. Rotation converged in 6 iterations. & & & & \\
\hline
\end{tabular}

